\title{
Influence of AM Fungus Glomus geosporum (Nicol. \& Gerd.) Walker on Chlorophyll content and Biochemical changes in four AMF disputed plants
}

Sharanappa Jangandi ${ }^{1}$, Narayan ${ }^{2}$, H.C. Lakshman ${ }^{3}$ and Chaitra B. Negalur ${ }^{3 *}$

${ }^{1}$ Zonal Agricultural and Horticultural, Research Station, Babbur Farm Hiriyur, Chitradurga dist-577598.

${ }^{2}$ Department of Environmental Science, Kuvempu University, Shankarghatta- 577451, Shimoga district.

${ }^{3}$ P.G. Department and Studies in Botany, Microbiology Laboratory, Karnatak University, Dharwad-580 003, India.

Received: November 27, 2016; Revised: November 29 2016; Accepted: December 12, 2016

\begin{abstract}
The function of mycorrhizae depends on the ability of the fungal symbiont. In the present study, the Glomus geosporum was inoculated on four amaranthaceae plants, Amaranthus oleraceae Hook. A.paniculata, A.spinosa and A. viridi has showed increased chlorophyll content in AM fungus inoculated plants over noninoculated plants, consequently the total carbohydrates and protein content was higher in mycorrhiza inoculated plants over the control or noninoculated plants. The results revealed that the enhanced stomatal conductance, photosynthesis and transpiration may be coupled with mycorrhizal inoculation on these four leafy vegetable plants, although these plants are disputed with AM fungal association.
\end{abstract}

Key words: AM fungus (Glomus geosporum); Chlorophyll; Carbohydrates; Proteins; Amaranthus spp.

\section{Introduction}

The importance of mycorrhizae in providing nutrition to most vascular plants and maintaining the health of ecosystem has been demonstrated since three and half decades ago. Arbuscular mycorrhizal (AM) fungi are ubiquitous and commonly associated with most plants in nature (Trappe and Fogel, 1977; Bagyaraj, 2006; Lakshman, 2009, 2014, Barthakar, 2014). The rangeland productivity with cropland and environmental production correlated with different mycorrhizal aspects has been reported by (Daug et al., 2008). Most of the plant species harbour different indigenous arbuscular mycorrhizal (AM) fungal population. The mycorrhizal fungi translocate nutrients to the host plant. The host provides photosynthates to the mycorrhizal fungi. The mycorrhiza fungal mycelium thus serves as highly efficient extensions of the root system.

Mycorrhizae are most active living soil fungi and it supply the basic enzymatic machinery for absorption, translocation and assimilating major mineral ions like phosphate and inorganic nitrogen required for symbiosis, while as the plant provides the particular ecological niche that is necessary for fungal growth and development (Martin and Hilbert, 1991; Lakshman, 2008). Arbuscular mycorrhizal fungi occur in most vegetation types and constitute an important component of the tropical soil micro flora (Cardoso et al., 2006). Arbuscular mycorrhizal fungi (AMF) have amply demonstrated their influence on the biochemical and physiological benefits conferred by them on potential host plants (Harley and Smith, 1983; Jalali, 1987; Bheemreddy and Lakshman, 2011).

\footnotetext{
*Corresponding Author:

Dr. Chaitra B. Negalur,

Microbiology laboratory,

P.G.Department of Botany,

Karnatak university, Dharwad, Karnataka, India.

E-mail: chainegalur@gmail.com
}

The function of all mycorrhizal systems depends on the ability of the fungal symbiont to absorb inorganic and organic nutrients available in soil. However, the recent studies suggest that arbuscular mycorrhizal fungal infection may change the biochemical composition of the host plant. It is considered as an important arbuscular mycorrhizal fungi and an alternative biofertilizer for agriculture environment. Hence, the present study was undertaken to investigate on influence of arbuscular mycorrhizal fungi on the biochemical aspects of four plants of amaranthaceae grown under green house conditions. Information on the effects of arbuscular mycorrhizal fungi on biochemical composition in such host plants is limited. Hence, an attempt was made to understand the changes in the metabolic activities of such experimental plants, infected by arbuscular mycorrhizal fungus.

\section{Materials and Methods}

Study area, Plant selection and Bioinoculant collection

Present experiment was conducted in the greenhouse of the Post Graduate Department of Studies in Botany, Microbiology Laboratory, Karnatak University, Dharwad-580003, Karnataka, India, where the temperature ranged from $26^{\circ} \mathrm{C}$ to $30^{\circ} \mathrm{C}$. The greenhouse conditions create a natural environment, where plants were sheltered against direct sunlight and rainfall. Four experimental plant species, viz. Amaranthus oleraceae Hook, Amaranthus paniculatus L. Amaranthus spinosa L. and Amaranthus viridis L. were selected. Seeds of all the four experimental plants were collected from the fields University of Agricultural Sciences, Dharwad. In order 
to decrease microbial contamination and to achieve healthy seedlings, seeds of experimental plants were surface disinfected with $1 \%$ sodium hypochlorite for $2-3$ minutes before sowing. The AM fungus Glomus geosporum, which were selected as AM inoculant and it was mass multiplied on Sorghum vulgare L. as a suitable host plant. The plant leaves were collected after 60 days of inoculation with AM fungi to estimate chlorophyll content was estimated following the procedure of (Arnon, 1949).

\section{Experimental setup}

The soil was dispensed into earthen pots measuring $20 \mathrm{~cm}$ height, $25 \mathrm{~cm}$ diameter, (4 $\mathrm{kg}$ autoclaved soil per pots) with sandy loamy soil in ratio of 1:1 (1 parts soil: 1 part sand). The soil mixture was sterilized and seeds were sown. $15 \mathrm{gms}$ of air dried arbuscular mycorrhizal inoculum was provided to each pot as a thin layer $2 \mathrm{~cm}$ below the soil surface to the selected four experimental plants, before sowing seeds into the respective pots. A quantity of soil inocula of arbuscular mycorrhizal fungus containing spores, hyphae and root fragments was thoroughly mixed into the soil. Sterilized experimental plants seeds were sown in each pot, after germination thinned to one plant in each pot. Control plant without AM fungi at inoculation was also maintained. Pots were arranged in a randomized complete block design (RBD) maintained in triplicates. Pots were watered an alternative day and Hogland plant nutrient solution about $2.5 \mathrm{ml}$ was provided to the seedling at the intervals of 15 days. Plants were uprooted after 60 days and some selected biochemical analyses were estimated.

Estimation of total Carbohydrates was adopted following the procedure of Phenol Sulphuric acid method (Dubois et al., 1956) Reagents:

Estimation of Protein was done according to the procedure of Bradford method, 1976.

\section{Results}

In this present study, arbuscular mycorrhizal fungus Glomus geosporum was inoculated on four experimental plants of amaranthaceae and their biochemical parameters were studied. The results revealed remarkable results when the plants were inoculated with arbuscular mycorrhizal fungi. The increased total chlorophyll content was shown in (Fig. 1).

Amaranthus oleraceae Hook. Mycorrhizal plants showed a considerable increase in biochemical content when compared to non-mycorrhizal plants. Application of Glomus geosporum showed significant increase in total carbohydrate i.e. $18.25 \pm 0.05 \mathrm{mg} / 100 \mathrm{~g}$ in mycorrhiza inoculated plants and it is recorded lower in control i.e., $8.13 \pm 0.55 \mathrm{mg} / 100 \mathrm{~g}$. Arbuscular mycorrhizal fungi stimulated the maximum production of protein in experimental plants. Inoculated plants showed higher content of protein about $12.15 \pm 0.02 \mathrm{mg} / 100 \mathrm{~g}$. Whereas, non-inoculated plant showed the least protein content $(1.2 \pm 0.02 \mathrm{mg} / 100 \mathrm{~g})$.
Amaranthus paniculatus L. inoculation of Glomus geosporum showed significant increase in total carbohydrates i.e. $5.73 \pm 0.50 \mathrm{mg} / 100 \mathrm{~g}$ in mycorrhizal plants and it is recorded lower in control i.e., $4.31 \pm 0.00 \mathrm{mg} / 100 \mathrm{~g}$. Arbuscular mycorrhizal fungi stimulated the maximum production of protein in experimental plants. Mycorrhiza inoculated plants showed higher content of protein about $6.36 \pm 0.01 \mathrm{mg} / 100 \mathrm{~g}$. whereas, noninoculated plant showed the least protein content $(03.85 \pm 0.05 \mathrm{mg} / 100 \mathrm{~g})$.

Amaranthus spinosus L. inoculation of Glomus geosporum showed significant increase in total carbohydrates i.e., $(6.19 \pm 1.1 \mathrm{mg} / 100 \mathrm{~g})$ in mycorrhizal plants and it is recorded lower in control i.e., $3.03 \pm 0.6 \mathrm{mg} / 100 \mathrm{~g}$. Arbuscular mycorrhizal fungi stimulated the maximum production of protein in experimental plants. Inoculated plants showed higher content of protein about $12.11 \pm 0.00 \mathrm{mg} / 100 \mathrm{~g}$. The non-inoculated plant showed the least protein content $(5014 \pm 0.30 \mathrm{mg} / 100 \mathrm{~g})$.

Amaranthus viridis L. inoculation of Glomus geosporum showed significant increase in total carbohydrates i.e., $11.16 \pm 0.1 \mathrm{mg} / 100 \mathrm{~g}$ in treated plant and it is recorded lower in control i.e., $4.41 \pm 0.5 \mathrm{mg} / 100 \mathrm{~g}$. Arbuscular mycorrhizal fungi stimulated the maximum production of protein in experimental plants. Inoculated plants showed higher content of protein about $06.45 \pm 0.10 \mathrm{mg} / 100 \mathrm{~g}$. Non-inoculated plant showed the least protein content $(04.25 \pm 0.05 \mathrm{mg} / 100 \mathrm{~g})$.

\section{Discusssion}

There is increased content of total Carbohydrates and Protein concentration was recorded in the present study as shown in (Table-1). Arbuscular mycorrhizal fungal inoculation significantly influenced the overall growth and nutrient component of the all four experimental plants. The use of AM fungi had a significant effect on total carbohydrates of all mycorrhizal inoculated plants compared to control. The maximum increase in total carbohydrates content was obtained, when soil was infested with Glomus geosporum. The least result were observed in non-inoculated plants.

Nermic and Meredith (1981), have stated the mycorrhizal and non-mycorrhizal plants are known to differ in their biochemical constitution particularly in the amino acid and protein fractions, similar results were obtained in the present study. Baltruschat and (Schonbeck, 1975 and Hosmani et al., 2011) had reported the protein content was high in AM fungi inoculated tomato plant than uninoculated control. Increased levels of protein in the inoculated plants could be attributed to either the presence of fungal proteins or post infectional stimulation of protein synthesis in the host plant, which is inconsistence with our reports. Krishna and Bagyaraj, 1983 and Gabriel and Lakshman, 2015 have recorded increased levels of protein in the inoculated plants of Niger could be attributed to either the presence of fungal proteins or post infectional stimulation of protein synthesis in the host plant which 
supports our results. Grimoldi et al., (2005) found no significant effect of arbuscular mycorrhizal fungi on starch and soluble carbohydrate in Lolium perenne L. which is completely in contrary to our findings. In the present study, our reports demonstrate for the first time that, inoculation of amaranthaceae seedlings with arbuscular mycorrhizal fungi improves biochemical accumulation in the green house condition.

In the present investigation, the total chlorophyll in leaves and the biochemical contents such as protein and total carbohydrates content were increased with the advancement age of the plant (Channabasava et al., 2014, Bheemereddy and Lakshman, 2015; Chaitra et al., 2016).
Mycorrhizal colonization in all the four experimental plants of amaranthaceae by arbuscular mycorrhizal fungi has the potential to increase allocation of carbohydrates to roots, representing a pathway for underground carbon fixation. Our study showed the remarkable results when, experimental plants were inoculated with AM fungi. Therefore, from the present study, it can be concluded that AM colonization increased plant growth chlorophyll content in leaves and biochemical compositions. And thus, AM fungi may play multiple roles in protection of plants against soil-borne pathogens, in increasing growth response of plant etc. and most importantly its biological nature makes it more beneficial to our ecosystem and environment.

Table 1: Showing the total chlorophyll content in four Amaranthaceae plant leaves of inoculated and noninoculated AM fungus Glomus geosporum at 60 days Treatment.

\begin{tabular}{|c|c|c|c|c|}
\hline S. No. & Treatment & Chlorophyll a & Chlorophyll b & Total Chlorophyll \\
\hline \multirow[t]{2}{*}{1} & $\begin{array}{c}\text { Amaranthus olereaceae Hook. } \\
\text { Noninoculation }\end{array}$ & 1.461 & 0.325 & 1.786 \\
\hline & $\begin{array}{l}\text { Inoculated with } \\
\text { Glomus geosporum }\end{array}$ & 1.969 & 0.456 & 2.425 \\
\hline \multirow[t]{2}{*}{2} & $\begin{array}{l}\text { Amaranthus paniculatus } \mathrm{L} \text {. } \\
\text { Noninoculation }\end{array}$ & 1.426 & 0.445 & 1.874 \\
\hline & Glomus geosporum & 1.837 & 0.512 & 2.349 \\
\hline \multirow[t]{2}{*}{3} & $\begin{array}{l}\text { Amaranthus spinosus L. } \\
\text { Noninoculation }\end{array}$ & 1.538 & 0.433 & 1.971 \\
\hline & $\begin{array}{l}\text { Inoculated with } \\
\text { Glomus geosporum }\end{array}$ & 1.941 & 0.605 & 2.546 \\
\hline \multirow[t]{2}{*}{4} & $\begin{array}{l}\text { Amaranthus Viridis L. } \\
\text { Noninoculation }\end{array}$ & 1.511 & 0.435 & 1.946 \\
\hline & $\begin{array}{l}\text { Inoculated with } \\
\text { Glomus geosporum }\end{array}$ & 2.019 & 0.538 & 2.557 \\
\hline
\end{tabular}

All the values are mean of four replicates.

Table 2: Showing the total carbohydrates and Protein content in noninoculated and inoculated with AM fungus on four leafy vegetable plants of amaranthaceae at 60 days.

\begin{tabular}{|c|c|c|c|}
\hline S1. No. & Treatment & $\begin{array}{c}\text { Totals Carbohydrates } \\
(\mathrm{mg} / 100 \mathrm{~g})\end{array}$ & $\begin{array}{c}\text { Protein } \\
(\mathrm{mg} / 100 \mathrm{~g} \text { of extract })\end{array}$ \\
\hline \multirow[t]{2}{*}{1} & $\begin{array}{c}\text { Amaranthus olereaceae Hook. } \\
\text { Noninoculation }\end{array}$ & $8.13 \pm 0.13$ & $6.12 \pm 0.02$ \\
\hline & $\begin{array}{l}\text { Inoculated with } \\
\text { Glomus geosporum }\end{array}$ & $18.25 \pm 0.05$ & $12.15 \pm 0.02$ \\
\hline \multirow[t]{2}{*}{2} & $\begin{array}{c}\text { Amaranthus paniculatus } \mathrm{L} \text {. } \\
\text { Noninoculation }\end{array}$ & $4.31 \pm 0.02$ & $3.85 \pm 0.05$ \\
\hline & $\begin{array}{l}\text { Inoculated with } \\
\text { Glomus geosporum }\end{array}$ & $5.73 \pm 0.43$ & $6.36 \pm 0.04$ \\
\hline \multirow[t]{2}{*}{3} & $\begin{array}{l}\text { Amaranthus spinosus } \mathrm{L} . \\
\text { Noninoculation }\end{array}$ & $3.03 \pm 0.00$ & $5.14 \pm 0.03$ \\
\hline & $\begin{array}{l}\text { Inoculated with } \\
\text { Glomus geosporum }\end{array}$ & $6.19 \pm 1.00$ & $12.10 \pm 0.00$ \\
\hline \multirow[t]{2}{*}{4} & $\begin{array}{c}\text { Amaranthus Viridis L. } \\
\text { Noninoculation }\end{array}$ & $4.41 \pm 0.00$ & $4.25 \pm 0.05$ \\
\hline & $\begin{array}{l}\text { Inoculated with } \\
\text { Glomus geosporum }\end{array}$ & $11.15 \pm 0.04$ & $6.45 \pm 0.01$ \\
\hline
\end{tabular}

All the values are mean of four replicates.

\section{References}

1. Baltruschat $\mathrm{H}$, and Schonbeck F. "The influence of endotrophic mycorrhiza on the infestation of tobacco by Thielaviopsis basicola”. Phytopathol. 84 (1975): 172.

2. Barthakar B. "Arbuscular mycorrhizal association, its potentiality to improve waste land inside proposed Kaziranga biosphere reserve, Assam, India”. Mycorrbiza News 26.3(2014): 2-3.
3. Bheemareddy VS, Lakshman HC. "Effect of AM fungus Glomus fasciculatum on the accumulation of metabolites in four varities of Triticum aestivum under short term water stress". Vegetos 24.1 (2011): 41-49.

4. Bhemmreddy VS, Lakshman HC. "Impact of cadmium phytotoxicity as photosynthetic rate and chlorophyll content in Triticum aestivum L. DWR225 variety". In: Major constrains and verdict of crop production. (ed.) ww. Bhale. Astral International (P) Ltd. New Delhi- India. (2015): 244-249. 
5. Bradford MM. "A rapid and sensitive method for the quantitation of microgram quantities of protein utilizing the principle of protein-dye binding". Anal. Biochem 72 (1976): 248-254.

6. Cardoso IM, Boddington C, Janssen $\mathrm{BH}$, Oenema O, Kuyper TW. "Differential access to phosphorus pools of an Oxisol by mycorrhizal and non-mycorrhizal maize". Commu. Soil Sci. Plant Anal 37(2006): 11-12.

7. Chaitra BN, Suresh BG, Lakshman HC. "Effect of AM fungus (Rhizophagus fasiculatus) on three Legimunous plant to improve chlorophyll and nutrients uptake" Sci. Res. Reporter 6.1(2016): 44-49.

8. Channabasava A, Lakshman HC, Muthukumar T. "Fly ash Mycorrhiza remediation through Paspalum scrobilatum L. inoculated with Rhirophagus fasiculatus". Comptes Rendus Biologies CRASS3- 331 (2014): 11.

9. Doug Y, Zhu YG, Smith FA, Wang Y, Chen BD. "Arbuscular mycorrhiza enhanced arsenic resistance of both write clover (Trifolum repens L.) and rye grass (Lolium perenne L.) plants in an arsenic soil". Applied Soil, ecol 35.1(2008): 213-225

10. DuBois M, Gilles K, Hamilton J, Rebers P, Smith F "Colorimetric method for determination of sugars and related substances". Analytical Chemistry 28.3(1956): 350356

11. Gabriel KP, Lakshman HC. "Assessment of Microbial inoculants on Enzyme activity and Chlorophyll content of Guizotia abyssinica (L.f) Cass plants Genotypes". International Journal of Applied Research 1.12(2015): 113-119.

12. Grimoldi AA, Kavanova M, Lattanzi FA, Schnyder H. "Phosphorus nutrition mediated effects of arbuscular mycorrhiza on leaf morphology and carbon allocation in perennial ryegrass". New Phytol 168(2005): 435-444.

13. Harley JL, Smith SE. (Eds) Mycorrhizal symbiosis. Academic Press, London (1983): 484.
14. Hosamani PA, Lakshman HC, Sandeepkumar K, Rashmi CH. "Antimicrobial activity of leaf extract of Andrographis paniculata. Wall”. Science Research Reporter 1.2(2011): 92-95.

15. Jalali BL. "Relevance of VA mycorrhizal system in increasing crop productivity in legume crops". In: Food Legume Improvement for Asian Farming Systems, (eds. E. S. Wallis and D. E. Byth) (1987): 342.

16. Krishna KR, Bagyaraj DJ. "Interaction between Glomus fasciculatum and Sclerotium rolfsii in peanut". Can. J. Bot 61(1983): 2349-2351.

17. Lakshman HC. "VAM Fungal biodiversity of forest tree species in dry deciduous forest of Dharwad". In: Forest diversity, (eds.) K. Muthuchelian, S. Kannaiyan and A. Gopalam). Associated Publishing Company, New Delhi, 2(2008): 223-230

18. Lakshman HC, Prashant G, Inamdar. "Symbiotic response of Eugenia bracteata Lam. to VA-mycorrhizal inoculation with different soil pH". Nat. J. of Life Sci 2.1\&2(2005): 161-164.

19. Martin F, Hilbert JL. "Morphological, biochemical and molecular changes during ectomycorrhiza development". Experientia. 47(1991): 321-331.

20. Nemec S, Meredith FI. "Amino acid content of leaves in mycorrhizal and non-mycorrhizal citrus root stocks. Ann. Bot 47(1981): 351-358.

21. Trappe JM, Fogel RD. "Ecosystematic functions of mycorrhizae Columbus State University Science Department". (1977): 7-16.

\section{Cite this article as:}

Sharanappa Jangandi, Narayan, H.C. Lakshman and Chaitra B. Negalur. Influence of AM Fungus Glomus geosporum (Nicol. Gerd.) Walker on Chlorophyll content and biochemical changes in four AMF disputed plants. Annals of Plant Sciences 6.01 (2017): 1527-1530. DOI: httb://dx.doi.org/10.21746/aps.2017.01.007 